\title{
COMMENT
}

\section{The walking dead}

\author{
Gregory A Petsko*
}

"Field Reporter: Are they slow-moving, chief? Sheriff McClelland: Yeah, they're dead. They're all messed up."

Night of the Living Dead (1968)

They come out of the night, shuffling towards us slowly, inexorably - pitiless, mindless and voracious. They care for nothing but their own continued existence. Unchecked, they will devour everything in their path.

They are the Zombie Ideas: ideas that seemingly died long ago but nonetheless still walk among us. Creationism, the Efficient Market, Iraq as the wellspring of the $9 / 11$ terrorists, faith as inherently superior to reason - Zombie Ideas, every one, and there are scores more. They should be dead, but they won't stay dead.

I've been thinking about zombies a lot lately. Not that I particularly want to; it's just that you can't avoid it if you live in the United States. Zombies are a dominant theme in American popular culture, along with vampires and werewolves. But whereas vampires are dangerously romantic (that biting of the neck is pretty obvious stuff), and werewolves are doomed tragic figures (Universal Studios' 1941 picture The Wolfman, starring Lon Chaney Jr and Claude Rains, is still one of the most moving films of all time), zombies are pretty much without redeeming social value. They don't think, communicate, or feel. All they do is stumble along, looking for human flesh to feed on.

It may surprise you to learn that the current idea of what zombies are like is a recent development and quite different from what people used to believe. Zombies traditionally were not resurrected corpses; they were living people who had lost all capacity for independent thought and action because they had fallen under the spell of a voodoo witch doctor.

That was before October 1968, when a young, Pittsburgh-based, independent filmmaker named George Romero released Night of the Living Dead. Filmed in glorious black-and-white for a tiny budget and starring a

*Correspondence: petsko@brandeis.edu

Rosenstiel Basic Medical Sciences Research Center, Brandeis University, Waltham, MA 02454-9110, USA cast of complete unknowns, the movie received surprising critical acclaim. Rex Reed wrote, "If you want to see what turns a B movie into a classic...don't miss Night of the Living Dead. It is unthinkable for anyone seriously interested in horror movies not to see it."

Forty-three years later, the judgment of the film as a classic still stands. It also was a socially significant film, although it wasn't meant to be. Romero made the unusual decision to cast an African-American actor, Duane Jones, in the lead, simply because he was the best actor who auditioned. Not only were black actors almost never given leading roles in mostly white movies in those days; when they were, their race was typically central to their character. In stark contrast, Ben, the character played by Jones, is the handsomest, most intelligent, most courageous figure in the film, and his death at the hands of a redneck party of zombie hunters at the end of movie, when he is mistaken for one of the walking dead, is not only bitterly ironic but savagely nihilistic.

Romero's stroke of genius - born out of the necessity of coming up with a new scare - was to change the concept of zombies from hypnotized live people to reanimated corpses with an appetite for human flesh. He combined elements of the traditional zombie - slow, relentless, mindless movement - with aspects of the ghoul of Arabic folklore, a creature who haunted graveyards and devoured unwary passers-by. Until Night, most post-World War II horror movies involved either mutated creatures grown to gigantic size or gruesome aliens from Mars or some other planet. The terror in Night is the terror of the familiar suddenly made deadly. The action takes place not on some lost continent or world beyond our own; the zombies invade a peaceful rural community in western Pennsylvania. As film historian Linda Badley puts it, these monsters aren't from outer space; “They're us." Coming at a time when the country was at war with itself over the quagmire of Vietnam, the idea of the dead rising and feeding on the living tapped not just into some primal fear; it somehow mirrored the grim reality of the moment.

So why the sudden resurge in popularity of the zombie film now? One reason might be a general increase in apocalyptic dread, due to the near economic collapse, threats of terrorism, scares about emerging infectious diseases, and concern about the possible catastrophic effects of global warming. Most of the post-apocalyptic 
films of the past decade have imagined a blighted landscape peopled largely with zombies - walking dead created either by some genetic experiment gone wrong or by some biological warfare agent. These movies play into a growing worry on the part of many Americans that science, particularly the life sciences, is out of control and being directed by amoral technocrats.

And of course, the notion that scientists care only about making discoveries and have no real concern for the possible harm their work might cause is one of the Zombie Ideas that movies and the right-wing press have kept alive for decades. Before the birth of the atomic bomb, there were a number of popular movies about scientists as heroes: Dr Erlich's Magic Bullet, The Story of Louis Pasteur, Madame Curie and so on. But for the last 60 years, scientists in films have chiefly been either victims of their own hubris (The Incredible Hulk, The Hollow Man) or nutcases (A Beautiful Mind, ReAnimator). This is one Zombie Idea that we could help kill for good, but instead we often shun opportunities to explain ourselves to the public, and deride those of our profession (Carl Sagan, for one) who do.

Perhaps the hardest to kill of all the Zombie Ideas is creationism - or, these days, any literal interpretation of the Bible. This particular walking corpse has been trying to break into our school system for some time, where it will devour the brains of our children if we let it. Kill the teaching of creationism in public schools and it rises again as intelligent design. Put that one down and up pops the latest incarnation: academic freedom. Nine states with Republican majorities in their state legislatures have introduced 'stealth creationism' bills in the guise of protecting academic freedom or encouraging critical thought since the end of last year. The two most recent are in - prepare for a shock here - Texas and Florida. The Texas bill, HB 2454, reads as follows:

\section{"PROHIBITION OF DISCRIMINATION BASED} ON RESEARCH RELATED TO INTELLIGENT

DESIGN. An institution of higher education may not discriminate against or penalize in any manner, especially with regard to employment or academic support, a faculty member or student based on the faculty member's or student's conduct of research relating to the theory of intelligent design or other alternate theories of the origination and development of organisms."

Now please note that there is no such thing as intelligent design research'. It's another Zombie Idea. No peerreviewed, respectable scientific publication has ever printed any research paper on this topic because there can't be one; intelligent design isn't about evidence, it's about faith. I have no problem with discussing it in courses in history, religion, or philosophy. But it has no place in the sciences, and any science teacher who teaches it is incompetent.

The Florida bill is really interesting. HB 1854 would actually require "a critical analysis" of the teaching of evolution in public schools. The bill is similar to legislation currently in committee in Tennessee, which says that educators may not be prohibited from "helping students understand, analyze, critique and review in an objective manner the scientific strengths and scientific weaknesses of existing scientific theories covered in the course being taught," but it is even more authoritarian in that it mandates this. You can get a pretty good sense of where this bill is coming from by one of its other requirements, namely to teach "the history and content of the Declaration of Independence, including national sovereignty, natural law, self evident truth, equality of all persons, limited government, popular sovereignty, and inalienable rights of life, liberty, and property, and how they form the philosophical foundation of our government." Limited government, by the way, wasn't part of the Declaration of Independence, and the inalienable rights listed by Thomas Jefferson did not include property. That they did, and that in addition the Founding Fathers intended the United States to be a Christian nation, is yet another Zombie Idea.

There are two Zombie Ideas that are particularly dangerous to genome biologists. The first is the idea that the best way to establish the true value of anything is by the free market. This particular walking corpse should have been killed by the financial crisis of 2008-2009, since one of the basic tenants of this stupid doctrine is that there can be no bubbles: the 'efficient markets' theory states that the market price of any asset reflects its actual value. Tell that to anybody holding securities backed by subprime mortgages. The hegemony of the market is a very popular idea in higher education circles these days, especially among professional academic administrators, bean-counters who claim to know the price of everything but in reality often understand the value of nothing. They close departments and start programs based not on sound educational philosophy or teaching experience, but on the fad of the moment and the misguided concept that students ought to be able to determine what they are taught.

You would think such administrators would be ashamed to utter the word 'market' after what we have all been through. Mathematically inclined free-market economists and financial geeks who knew nothing about human nature and trusted their models blindly were largely responsible for the mess the world is in at the moment - yet they remain, inexplicably, zombie-like in their ability to come back and influence political and social policies when they ought to be in a public pillory. 
(There's a lesson there for systems biology, by the way: put not your trust in models unless they are firmly grounded in an understanding of the way living organisms actually work.) We ought to engrave this slogan on every university administration building in every country on earth: the only market that has any place in higher education is the marketplace of ideas.

The second Zombie Idea that scientists should fear is the idea that Big Science is our friend. Don't worry about the money being poured into these new Big Science initiatives, we are told, because the data from such programs will generate tons of great research ideas for individual investigator-initiated, hypothesis-driven research projects. That, after all, was how the Human Genome Project was sold to the scientific community, and didn't that pay off big?

Well, yes, I think it did, but there are two fallacies in that argument. One is in the assumption that all big science programs are equally valuable. I haven't seen nearly enough good science, or useful data, emerge from either the Protein Structure Initiative or genome wide association studies, to give just two examples, to justify their continued existence. As far as I'm concerned, they are just walking corpses, feeding on the resources that the rest of us need to stay alive. The other is the fallacy that the pie is not finite. The Human Genome Project happened to coincide roughly with the doubling of the $\mathrm{NIH}$ budget, so there was an expanding pie that could feed both that huge endeavor and the research projects of individual investigators. But the pie hasn't been expanding for several years now, and there is no indication that it will do so in the immediate future. So every Big Science initiative directly consumes resources that are needed for the curiosity-driven, hypothesisbased work from which the real breakthroughs have historically come. In a time of static or dwindling resources, Big Science is friend to no one but itself.

And that, in the end, may be where the popularity of the zombie films is really coming from. We are living in an age of scarcity, whether of water, oil, jobs, food, or research funding. When resources are scarce, and you are not sure that there will be enough to keep you going, everyone around you is a potential threat. You are in their way, and they have no more use for you than a zombie does. But it's important to remember that ideas that should have died a long time ago are largely why the world is in the state it's in.

Zombie Ideas are like the walking dead themselves: relentless, unthinking, uncaring, and very hard to kill. Which is all the more reason why we have to keep trying.

Published: 31 March 2011

doi:10.1186/gb-2011-12-3-108

Cite this article as: Petsko GA: The walking dead. Genome Biology 2011, 12:108. 